\title{
MONOARTICULAR ARTHRITIS IN CHILDREN
}

BY

\author{
E. G. L. BYWATERS AND B. M. ANSELL \\ M.R.C. Rheumatism Research Unit, Canadian Red Cross Memorial Hospital, Taplow, Maidenhead, Berks.
}

Chronic monoarticular arthritis often presents a diagnostic problem of considerable therapeutic responsibility. Even before the introduction of antibiotics, the treatment of a joint affected by rheumatoid arthritis was very different from that of one affected by tuberculosis, and this difference is even more marked today. These two conditions and the results of trauma, including osteochondritis, are probably the three most common causes of monoarticular arthritis in both adults and children, but there are other rare conditions such as pigmented villonodular synovitis, haemangioma, synovioma and other tumours, hyperparathyroidism, and infections such as brucellosis, histoplasmosis, syphilis, or blastomycosis which must be remembered, and Kelly, Weed, and Lipscomb (1963) have described chronic joint infections by non-tuberculous acid-fast organisms as the result of injections. Even in adults these are all very rare, and in children in Great Britain, tuberculosis, rheumatoid arthritis, and the effects of trauma account for the vast majority of cases with a single joint involvement. Ultimately it may be found that a child presenting with an inflamed non-suppurative joint may develop signs of ankylosing spondylitis, psoriatic arthritis, or ulcerative colitis, but these may be quite impossible to differentiate clinically, radiologically, or histologically in the early stage when only one peripheral joint is affected, and such cases are quite rightly treated as rheumatoid arthritis until some other elucidating symptoms or signs appear. Besides circumstantial evidence, such as the presence of infection elsewhere in the body, a positive Mantoux test, or a history of trauma, or of exposure to acidfast infection, the most direct diagnostic evidence comes from examination of the joint itself, its fluid, and the associated lymph glands (Arden and Scott, 1947). In joint tuberculosis, however, the local lymph glands may not help in the diagnosis, and even the synovial fluid may be negative on culture or guinea-pig inoculation. We have therefore felt that all such cases should have a synovial biopsy, with histological and bacteriological examination of the tissue.

\section{Material}

In the last 15 years, out of a total of 316 cases of definite Still's disease (criteria cited by Ansell and Bywaters, 1959), 33 cases of monoarticular joint involvement were seen. This was defined as pain and swelling with or without limitation of movement, lasting for at least 3 months without the involvement of another joint. The following is an account of these cases, which have all been followed to date, paying particular attention to the course of the disease, whether other joints have become involved, whether the eye has been affected, and the histological findings at biopsy. All these 33 cases were considered as examples of rheumatoid arthritis, whether this be a single entity, or as is possible, more than one. We have excluded a few cases referred with this diagnosis which on examination showed radiological evidence of traumatic aetiology, such as osteochondritis dissecans or chondromalacia, or biopsy evidence of pigmented villonodular synovitis. No case of tuberculosis or chronic infection has been referred under this diagnosis, although acute monoarticular arthritis of infective origin has been admitted and of course also excluded. Appropriate investigations, including slit-lamp examination (Mr. Smiley), chest and joint $x$ rays, Mantoux test, Waaler-Rose and latex tests, were done in each case. Sacro-iliac $x$ rays were read independently with excellent agreement. Serum electrophoresis revealed no hypogammaglobulinaemia. Synovial fluid or membrane was sterile in all cases cultured. Twenty of the 33 were seen within one year of onset, but as there was little difference in results between those first seen within a year and those seen after, both are considered together.

\section{Results}

The knee was the joint most commonly involved, occurring in 23 of the 33 cases, with the ankles as the next most commonly involved (5), and occasion- 
ally other joints. Twenty of the 33 patients were girls and one-third were below 4 years of age at the time of onset (Table I).

TABLE I

MONOARTICULAR ONSET OF STILL'S DISEASE

\begin{tabular}{|c|c|c|c|c|c|}
\hline \multicolumn{2}{|c|}{ Total No. of Cases } & . & .. & 33 & \\
\hline Sex & $\begin{array}{l}\text { Male } \\
\text { Female }\end{array}$ & 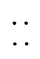 & .. & & $\begin{array}{l}13 \\
20\end{array}$ \\
\hline $\begin{array}{l}\text { Mean Age at Or } \\
\text { No. below } 4 \text { yrs }\end{array}$ & $\begin{array}{c}\text { set (yrs) } \\
\ldots\end{array}$ & $\because$ & .. & $6 \cdot 1$ & 11 \\
\hline Joint Involved & $\begin{array}{l}\text { Knee .. } \\
\text { Ankle } \\
\text { Wrist ... } \\
\text { Midtarsal } \\
\text { Toe .. }\end{array}$ & $\begin{array}{l}\ldots \\
\cdots \\
\cdots \\
\cdots\end{array}$ & $\begin{array}{l}. \\
\therefore \\
\therefore \\
. .\end{array}$ & $\begin{array}{r}23 \\
5 \\
2 \\
1 \\
3\end{array}$ & \\
\hline
\end{tabular}

These patients have been followed for up to 15 years (mean 6.5) and can be classified in three groups.

I. Monoarticular.-Fourteen of the 33 have remained with disease confined to the single joint.

II. Oligoarticular*.-Seven have progressed to involvement of one or two other joints.

III. Polyarticular.-Twelve have gone on to a more generalized involvement with at least four joints affected.

Fifteen of the nineteen cases developing further joint involvement (Groups II and III) did so within

" This term is prefered to "pauciarticular" (Griffin, Tachdjian, and Green, 1963) because of the analogy with the long accepted hybrids "monoarticular" and "polyarticular". the first year (range 3 months to 7 years; average $13 \cdot 7$ months) (Table II).

Iritis was present in three cases when first seen by us and developed in three further cases, giving an over-all incidence of 18 per cent. This occurred fairly equally in all three follow-up groups, i.e. it was irrespective of whether the course was monoarthritic (2/14), oligoarthritic (1/7), or polyarthritic $(3 / 12)$.

Sacro-iliitis with erosions developed in three cases, two bzcoming polyarticular (one with iritis) and one remaining monoarticular. The six cases with iritis had negative Waaler-Rose tests and only one had sacro-iliac erosions. The Waaler-Rose test was positive in one patient only, at a titre of $1: 128$ and on repeated occasions: this was a girl aged 11 at onset, with arthritis in one wrist, who 5 years later developed polyarthritis with erosions in the hands and feet.

Increase in limb length as a growth anomaly occurred in six of the fourteen cases remaining monoarticular, and one example was also seen among the twelve with polyarthritis, and one among the seven with oligoarthritis. Epiphyseal enlargement was also predominant in Group I (Table III). Increase in size of epiphysis and length of bone occurred in general amongst those with an early onset whether the whole series or those in Group I only are considered. Supra-condylar fractures of the femur

TABLE II

COURSE IN CASES OF STILL'S DISEASE WITH MONOARTICULAR ONSET

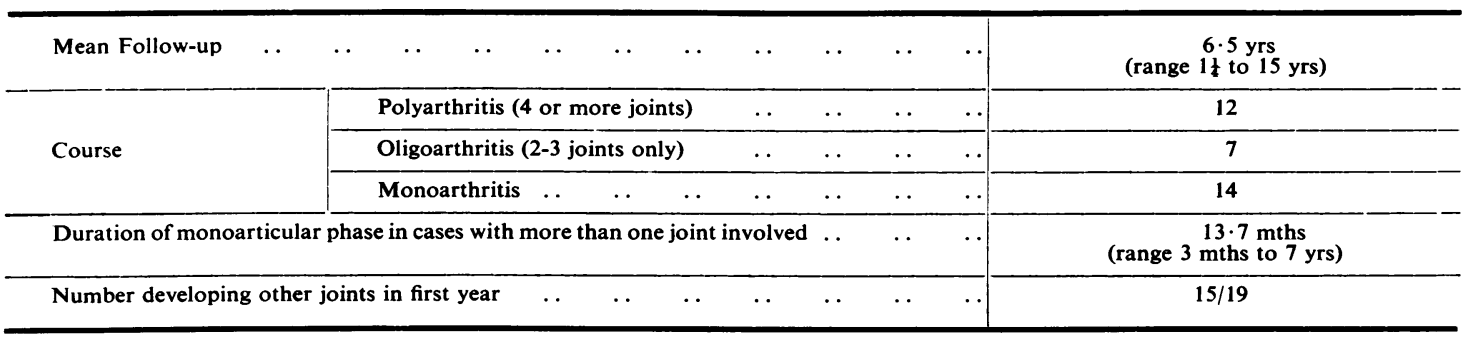

TABLE III

GROWTH ANOMALIES IN PATIENTS WITH STILL'S DISEASE WITH MONOARTICULAR ONSET

\begin{tabular}{|c|c|c|c|c|c|c|c|}
\hline \multicolumn{4}{|c|}{ Growth Anomalies } & \multirow{2}{*}{$\begin{array}{c}\text { Polyarthritis } \\
\begin{array}{c}1 \\
2 \\
9\end{array}\end{array}$} & \multirow{2}{*}{$\begin{array}{c}\text { Oligoarthritis } \\
\begin{array}{c}1 \\
0 \\
6\end{array}\end{array}$} & \multirow{2}{*}{$\begin{array}{c}\text { Monoarthritis } \\
\begin{array}{c}6 \\
1 \\
7\end{array}\end{array}$} & \multirow{2}{*}{$\begin{array}{c}\begin{array}{c}\text { Mean Age at } \\
\text { Onset (yrs) }\end{array} \\
\begin{array}{c}3 \cdot 5 \\
8 \cdot 3 \\
6 \cdot 7\end{array}\end{array}$} \\
\hline Clinical & $\begin{array}{l}\text { Increase } \\
\text { Decrease } \\
\text { No effec }\end{array}$ & $\begin{array}{l}\text { in li } \\
\text { e in } 1 \\
\text { t. . }\end{array}$ & $\begin{array}{l}\text { length } \\
\text { b length.. } \\
\ldots \quad \ldots\end{array}$ & & & & \\
\hline \multirow{3}{*}{ Radiological Epiphyseal Enlargement } & Present & . & . & 3 & 3 & 11 & $4 \cdot 8$ \\
\hline & Absent & . & .. & 9 & 4 & 3 & $7 \cdot 7$ \\
\hline & Total & .. & .. & 12 & 7 & 14 & \\
\hline Mean Age at Onset (yrs) ... & .. & .. & .. & $6 \cdot 4$ & $2 \cdot 2$ & $5 \cdot 7$ & \\
\hline
\end{tabular}




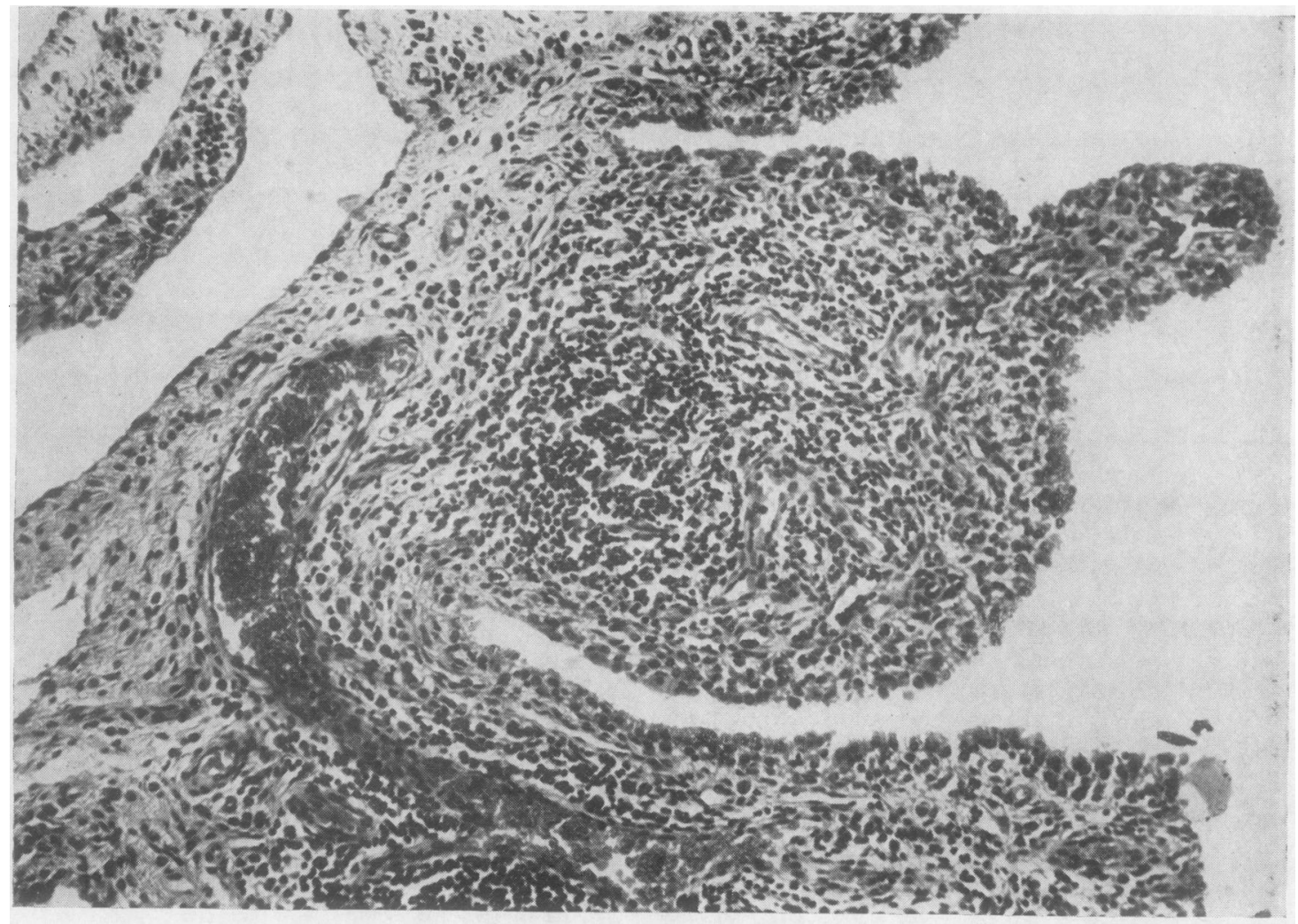

Fig. 1.-Classical rheumatoid synovial membrane with hyperplasia, lymphocyte aggregations, plasma cell infiltration, and fibrin deposition. This was obtained from the knee of a 2-year-old girl, 8 months after the onset of swelling. The arthritis remained monoarticular and had settled completely by the 5-year follow-up. Subsequent follow-up for a further 9 years has shown no recurrence of arthritis. Haematoxylin and eosin. $\times 160$.

occurred in four cases, three among those remaining monoarticular, the fourth just as she had become polyarticular.

Biopsies were done and seen by us in all but three cases. These three exceptions all later developed generalized polyarthritis. Two of the thirty biopsies were unsuitable for histological evaluation. Eight of the remaining 28 biopsies showed a classical rheumatoid synovial membrane with hyperplasia, lymphocyte aggregations, plasma cell infiltration, and fibrin deposition (Fig. 1), and from the histological viewpoint those who remained monoarticular or later developed polyarthritis were indistinguishable (Fig. 2, opposite).

A further eight showed similar but less marked changes, and twelve in all showed somewhat atypical histological changes consisting of mild synovitis with little lymphocyte or plasma cell accumulation (Figs. 3 and 4, overleaf). One possible explanation for this is the variability of the synovial membrane from place to place.
Fig. 5 (overleaf) taken from the same biopsy specimen as Fig. 2, shows comparatively mild synovitis compared with the classical rheumatoid infiltration at the other site.

There was little correlation between the subsequent course, whether polyarticular, oligoarticular, or monoarticular, and the biopsy findings (Table IV, opposite).

Remission occurred in fifteen of the 33 cases (Table V). As might be expected, the disease at follow up was inactive in ten out of thirteen of those remaining monoarticular, but was active in nine out of eleven of the polyarticular group.

\section{Discussion}

Grokoest, Snyder, and Ragan (1957) reported that 39 per cent. of their 110 patients had commenced with one joint only, but that other joints had become involved within a month in a number of cases. Similarly, Edström (1958) noted that 32 per cent. 


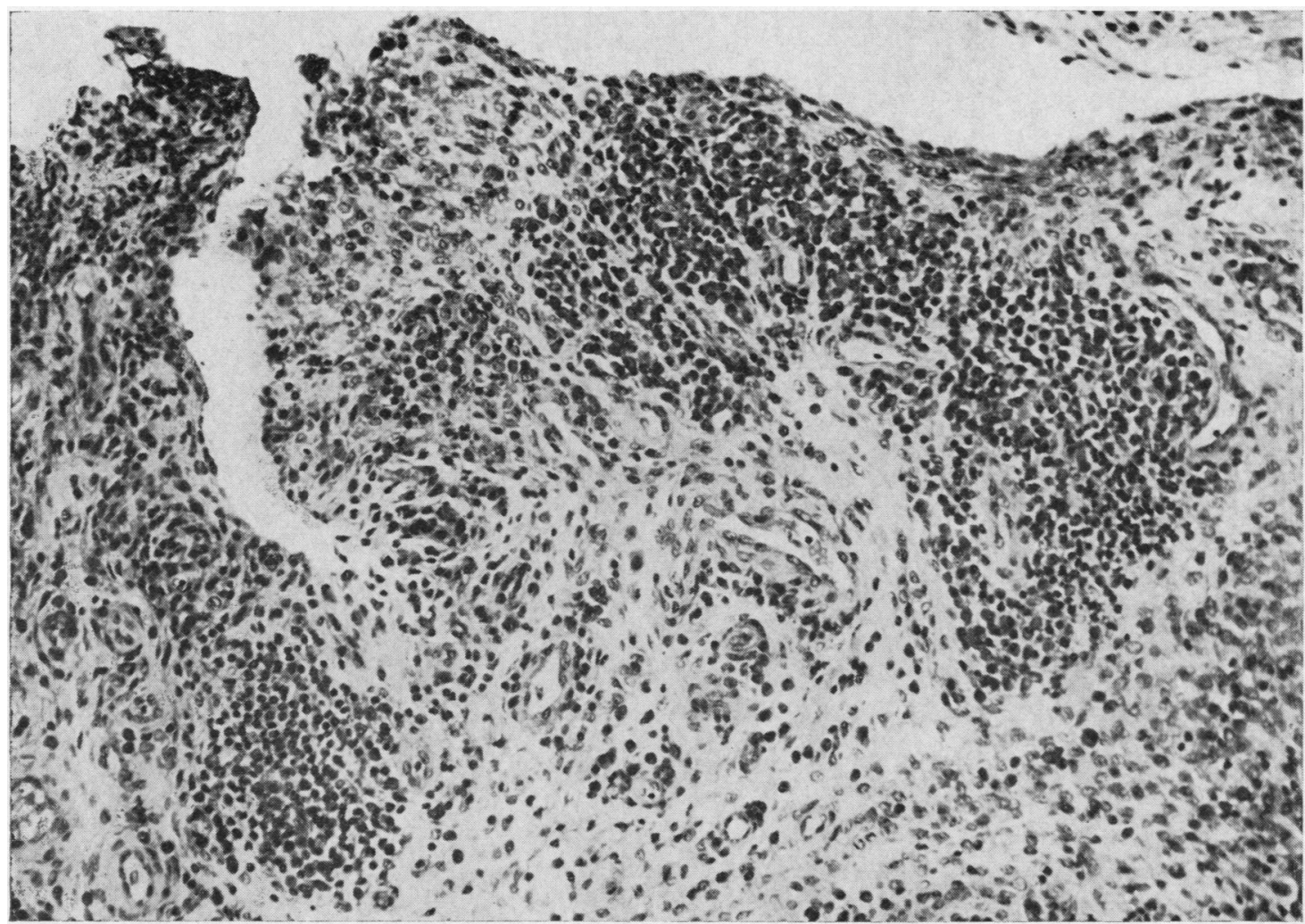

Fig. 2.-Classical rheumatoid synovial membrane obtained from the left ankle of an 18-months-old girl. At this time, the joint had been swollen for 3 months; 4 months later, polyarthritis developed. Haematoxylin and eosin. $\times 150$.

TABLE IV

MONOARTICULAR ONSET OF STILL'S DISEASE

CORRELATION OF HISTOLOGICAL APPEARANCE OF SYNOVIAL MEMBRANE WITH COURSE

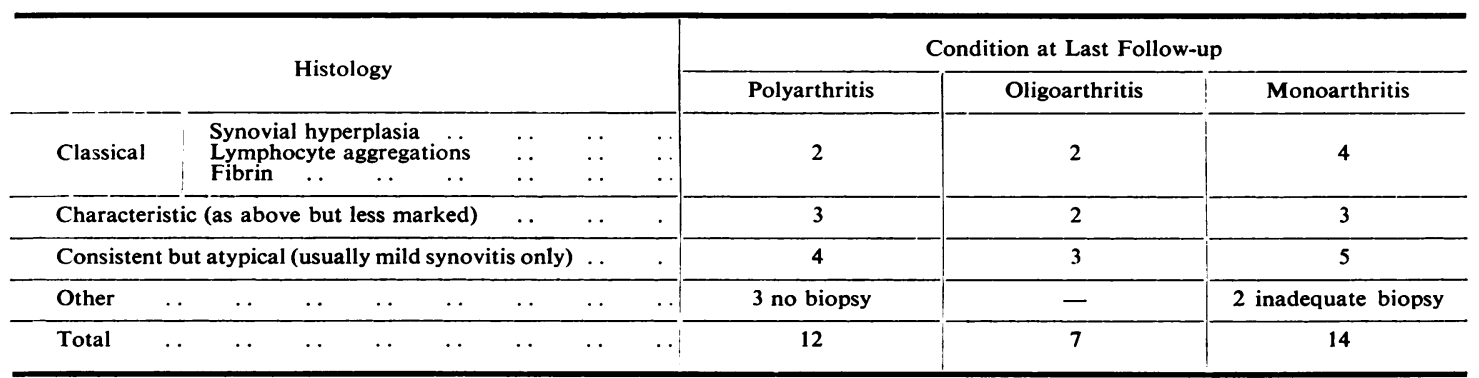

of his 161 cases began with one joint involved and that ten ( 6 per cent.) of them persisted indefinitely in a single joint. At this Unit a patient was not regarded as having a monoarticular onset unless involvement of a single joint had persisted for a minimum of 3 months, and this may well account for our somewhat lower incidence (10 per cent.). This dividing line was used because it was felt that those cases in which one joint only was affected for some time were the most difficult as regards diagnosis and management.

The sex and age at onset of these cases did not differ significantly from that of the children with Still's disease as a whole, nor was the incidence of 


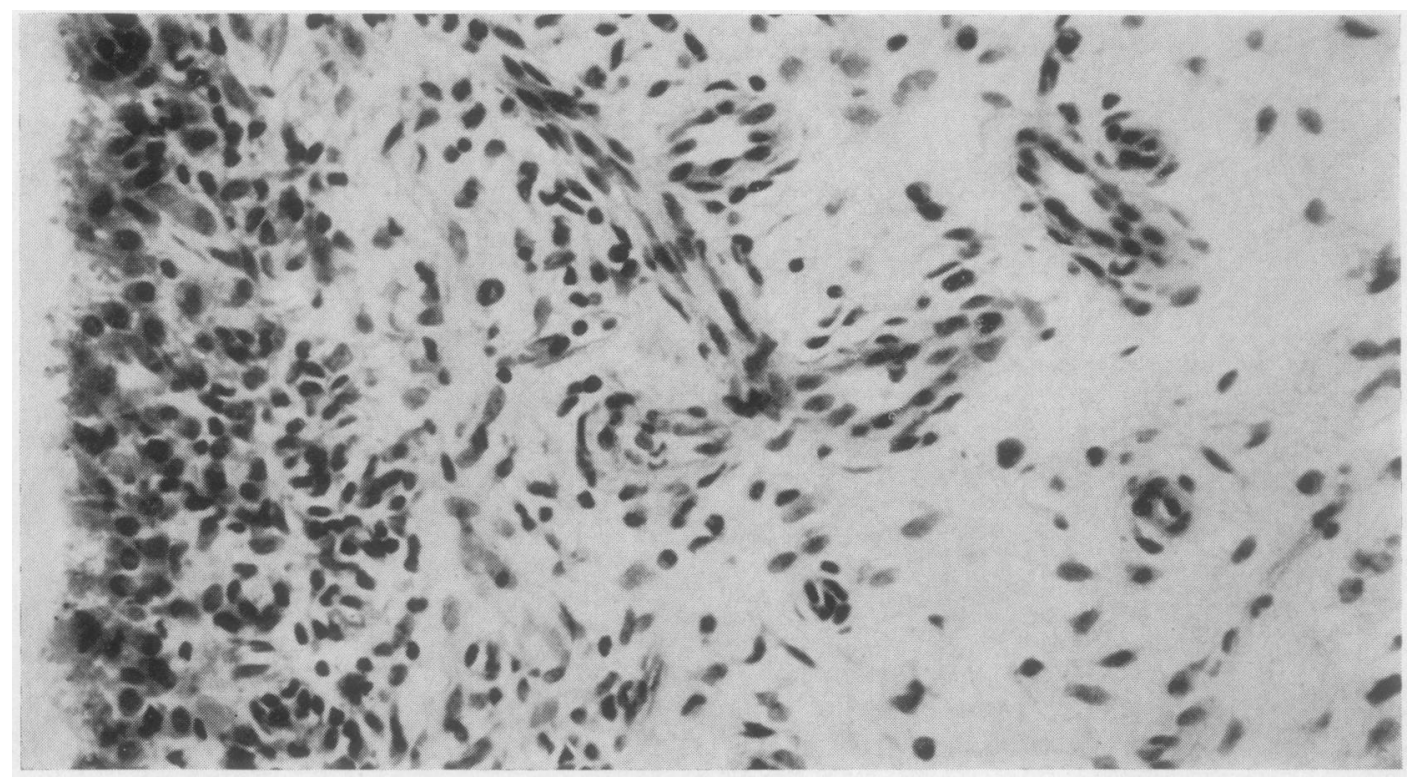

Fig. 3.-Mild synovitis of the left knee with sparse lymphocyte infiltration and a few plasma cells, obtained from a 4-year-old girl who 2 years later developed an effusion in the right knee. She has now been followed for 12 years. No other joints have been affected and her knees have now settled. Haematoxylin and eosin $\times 350$.

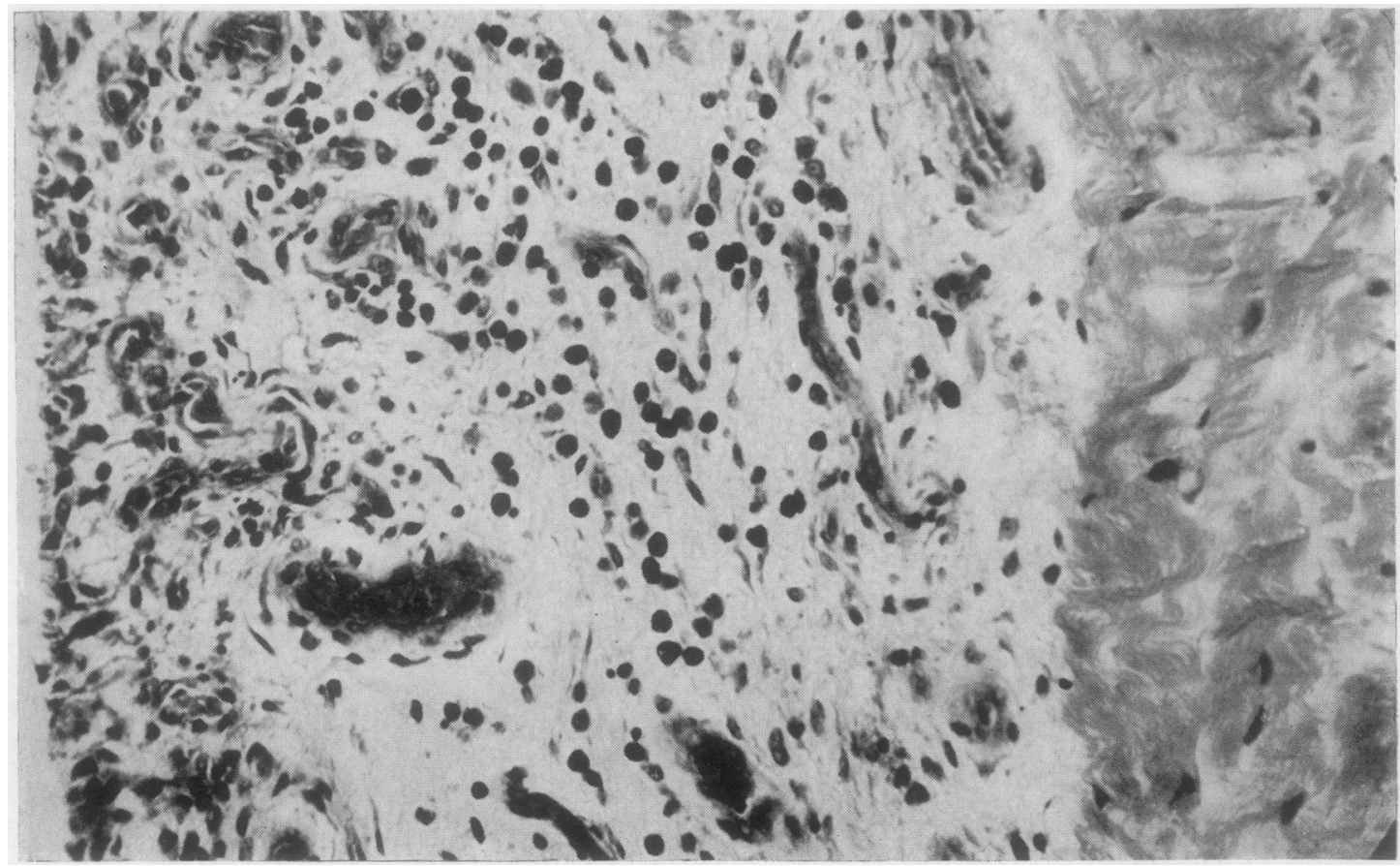

Fig. 4.-Mild synovitis in a boy of 14 who had had a persistently swollen knee for 7 weeks. The knee remained intermittently troublesome for 3 years and has now been normal for 2 years. Haematoxylin and eosin. $\times 300$ 


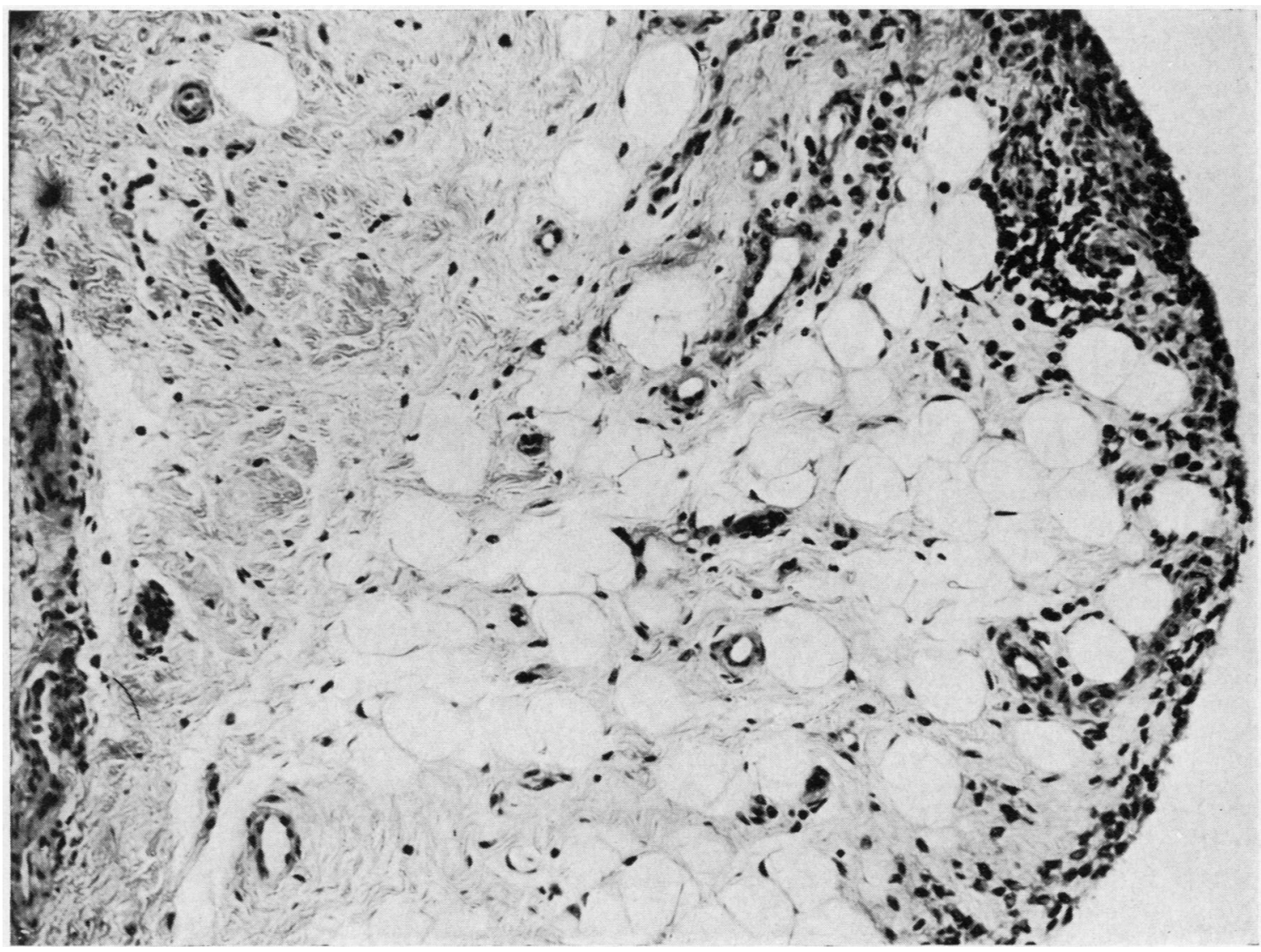

Fig. 5.-Mild synovitis seen in the same biopsy of ankle as illustrated in Fig. 2, with classical changes, showing the variability which can occur in one specimen. Haematoxylin and eosin. $\times 160$.

TABLE V

RESIDUAL ACTIVITY IN CASES OF STILL'S DISEASE WITH MONOARTICULAR ONSET

\begin{tabular}{|c|c|c|c|c|c|c|c|c|}
\hline \multirow{2}{*}{\multicolumn{4}{|c|}{ Condition at Follow-up }} & & \multirow{3}{*}{$\begin{array}{c}\text { Total Cases } \\
13 \\
\end{array}$} & \multicolumn{3}{|c|}{ Course of Disease } \\
\hline & & & & & & \multirow{2}{*}{$\frac{\text { Monoarticular }}{10}$} & \multirow{2}{*}{$\frac{\text { Oligoarticular }}{3}$} & \multirow{2}{*}{$\begin{array}{c}\text { Polyarticular } \\
0\end{array}$} \\
\hline Inactive & .. & . & .. & .. & & & & \\
\hline Inactive but with & niting & esidua & . & $\cdots$ & 2 & 1 & 1 & 0 \\
\hline Slightly active .. & .. & .. & $\ldots$ & $\cdots$ & 2 & 0 & 0 & 2 \\
\hline Active..$\quad \ldots$ & .. & .. &.. &.. & 13 & 2 & 2 & 9 \\
\hline $\begin{array}{l}\text { Lost to Series .. } \\
\text { Dead } \ldots\end{array}$ & $\because$ & $\therefore$ & $\because$ & $\because$. & $\begin{array}{l}2 \\
1\end{array}$ & $\begin{array}{l}0 \\
1\end{array}$ & $\begin{array}{l}1 \\
0\end{array}$ & $\begin{array}{l}1 \\
0\end{array}$ \\
\hline Total ... & .. & .. & .. &. & 33 & 14 & 7 & 12 \\
\hline
\end{tabular}


sacro-iliac change nor positive sheep cell tests very different. The relative frequency of onset below the age of 4 was also noted by Griffin and others (1963), who noted too the frequency of knee and ankle involvement such as we have observed, as well as of epiphyseal changes in this type of case. Contrary to their experience, however, fever and rash were occasionally seen, and were of diagnostic value in a child with a single joint involved. The incidence of iritis in this group was 18 per cent. compared with 8.9 per cent. in our total series. Although this occurred fairly equally in all three follow-up groups, it indicates that careful review of the eyes should not be omitted just because a patient has only one or a few joints involved. A similar high incidence of eye involvement (six out of forty) was reported by Cassidy, Brody, and Martel (1964), as was the frequency of over-growth on the affected side.

An unexpected finding was the occurrence of supra-condylar fractures of the femur on the affected side in three patients with persisting monoarticular involvement of the knee joint, and in two of these patients this occurred twice. The incidence is similar to that seen in our whole series of patients not treated with steroids (Badley and Ansell, 1960).

In our experience, histology was of great value in excluding the presence of infection and in establishing a diagnosis, but did not allow one to predict the course of the disease.

\section{Summary}

33 out of 316 patients with definite juvenile rheumatoid arthritis presented with monoarticular involvement for at least 3 months. Nineteen developed further joint involvement under observation, and in fifteen this occurred within a year from the involvement of the first joint. Fourteen patients remained with one single joint involved for a followup period of from 3 to 14 years (mean 6.5), and in eleven of these the disease was inactive at followup. Iritis was seen in six out of 33, and sacro-iliac change without spinal involvement in three out of 32 , and the Waaler-Rose test was positive in only one case. Synovial membrane biopsies taken from affected joints in thirty cases showed no correlation between the histology and the subsequent course.

\section{REFERENCES}

Ansell, B. M., and Bywaters, E. G. L. (1959). Bull. rheum. Dis., 9, 189.

Arden, G. P., and Scott, J. C. (1947). Brit. med. J., 2, 87.

Badley, B. W. D., and Ansell, B. M. (1960). Ann. rheum. Dis., 19, 135.

Cassidy, J. T., Brody, G. L., and Martel, W. (1964). Arthr. and Rheum., 7, 298.

Edström, G. (1958). Ibid., 1, 497.

Griffin, P. P., Tachdjian, M. O., and Green, W. T. (1963). J. Amer. med. Ass., 184, 23.

Grokoest, A. W., Snyder, A. I., and Ragan, C. (1957). Bull. rheum. Dis., 8, 147.

Kelly, P. J., Weed, L. A., and Lipscomb, P. R. (1963). J. Bone Jt Surg., 45-A, 327.

\section{L'arthrite mono-articulaire chez l'enfant}

\section{RÉSUMÉ}

Chez 33 sur 316 malades atteints d'arthrite rhumatismale juvénile, l'atteinte était mono-articulaire pendant au moins 3 mois. Dix-neuf d'entre eux développèrent en cours de l'observation l'arthrite des autres articulations et chez quinze d'entre eux celle-ci se produisit au cours de la première année dès la première atteinte. Chez 14 malades l'atteinte d'une seule articulation persista pendant la période d'observation de 3 à 14 mois (moyenne 6,5 ) et chez onze d'entre eux la maladie se montra nonévolutive. L'irite fut observée chez 6 sur 33, une lésion sacro-iliaque sans atteinte vertébrale chez 3 sur 32 , et la réaction de Waaler-Rose fut positive dans un cas seulement. Des biopsies de la membrane synoviale prélevées sur des articulations atteintes dans 30 cas ne montrèrent aucune corrélation entre l'aspect histologique et l'évolution subséquente.

\section{Artritis mono-articular en el niño}

\section{SUMARIO}

De 316 enfermos con artritis reumatoide juvenil, 33 tuvieron una sola articulación afecta durante al menos tres meses. Durante el período de observación 19 de estos desarrollaron una artritis en otras articulaciones y en 15 de ellos esta se produjo durante el primer año desde el primer ataque. En 14 enfermos la artritis mono-articular persistió durante el período de observación de 3 a 14 meses (un promedio de 6,5) y en 11 de ellos la enfermedad se mostró non-evolutiva. Una iritis fué observada en 6 de 33 casos, una lesión sacro-ilíaca sin implicación vertebral en 3 de 32 casos, y la reacción de Waaler-Rose fué positiva en un solo caso. Biopsias de la sinovia de las articulaciones afectas en 30 casos no mostraron correlación alguna entre el cuadro histológico y la evolución subsiguiente. 